\title{
S1P-S1p2 Signaling in Cardiac Precursor Cells Migration
}

\author{
Hajime Fukui, Shigetomo Fukuhara, and Naoki Mochizuki
}

\author{
Keywords \\ Zebra fish $\bullet$ Sphingosine-1-phosphate $\bullet$ Cardia bifida $\bullet$ Endoderm
}

During embryogenesis, zebra fish cardiac precursor cells (CPCs) originating from anterior lateral plate mesoderm migrate toward the midline between the endoderm and the yolk syncytial layer (YSL) to form cardiac tube. The endoderm functions as a foothold for CPCs as evidenced by the endodermal mutants (cas/sox32, sox 17, oep, fau/gata5, and bon) showing two hearts (cardia bifida) [1]. Furthermore, mutant zebra fish (toh) lacking sphingosine-1-phosphate (S1P) transporter which is expressed in the YSL show two hearts [2], indicating the essential role for S1P-mediated signal in cardiac development. This is also supported by a S1p2 receptor mutant ( $\mathrm{mil}$ ) which exhibits two hearts [3]. However, it is still unclear how $\mathrm{S} 1 \mathrm{P}$ released from YSL regulates CPC migration.

$\mathrm{S} 1 \mathrm{p} 2$ is expressed in the endoderm. Thus, we assume that $\mathrm{S} 1 \mathrm{P}$ released from the YSL might activate S1p2 expressed in the endoderm, thereby regulating CPC migration. One possibility is that S1p2-mediated signal controls the endoderm formation as a foothold for CPCs. Another possibility is that endodermal cells activated by S1p2 might secrete the chemokines which accelerate CPC migration or secrete the extracellular matrix proteins for guiding CPC movement.

To test these possibilities, we need to delineate the downstream signaling of $\mathrm{S} 1 \mathrm{p} 2$. Recently, $\mathrm{G} \alpha_{13}$ is reported to inhibit Hippo-mediator Lats1/2 kinase through a RhoGEF/Rho/Rho-kinase signaling $[4,5]$. We demonstrate that the inhibition of Hippo signaling in the endoderm by activated S1p2 is essential for endodermal cell

H. Fukui • S. Fukuhara • N. Mochizuki $(\bowtie)$

Department of Cell Biology, National Cerebral and Cardiovascular Center Research Institute,

Fujishirodai 5-7-1, Suita, Osaka 565-8565, Japan

e-mail: nmochizu@ncvc.go.jp

T. Nakanishi et al. (eds.), Etiology and Morphogenesis of Congenital Heart Disease, DOI 10.1007/978-4-431-54628-3_14 
Fig. 14.1 A model of S1P-S1p2 signaling regulated CPC migration. S1P secreted from the yolk activates S1p2 in the endoderm. Hippo signaling acts downstream of S1P-S1p2 signaling and maintains the endoderm to act as scaffolds for CPC migration

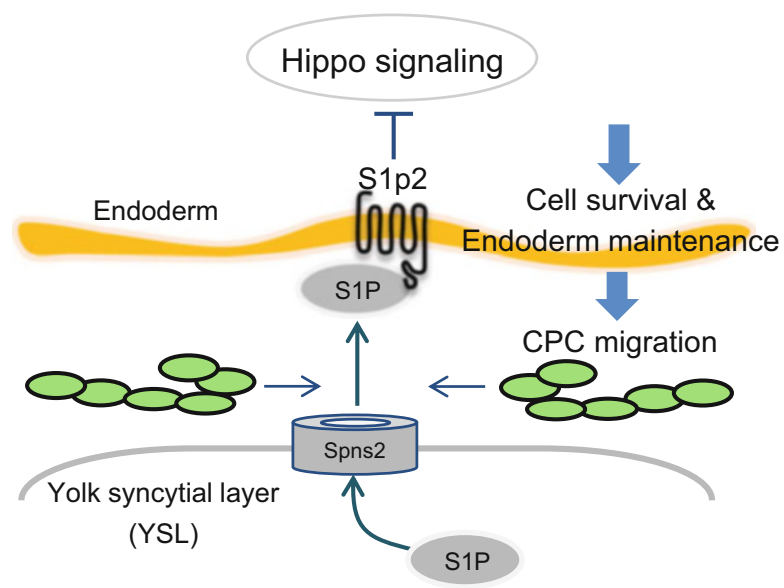

survival and that the endoderm maintained by S1P signaling indeed becomes the foothold for CPC migration (Fig. 14.1).

Open Access This chapter is distributed under the terms of the Creative Commons AttributionNoncommercial 2.5 License (http://creativecommons.org/licenses/by-nc/2.5/) which permits any noncommercial use, distribution, and reproduction in any medium, provided the original author(s) and source are credited.

The images or other third party material in this chapter are included in the work's Creative Commons license, unless indicated otherwise in the credit line; if such material is not included in the work's Creative Commons license and the respective action is not permitted by statutory regulation, users will need to obtain permission from the license holder to duplicate, adapt or reproduce the material.

\section{References}

1. Kikuchi Y, et al. casanova encodes a novel Sox-related protein necessary and sufficient for early endoderm formation in zebrafish. Genes Dev. 2001;15(12):1493-505.

2. Kawahara A, et al. The sphingolipid transporter spns2 functions in migration of zebrafish myocardial precursors. Science. 2009;323(5913):524-7.

3. Kupperman E, et al. A sphingosine-1-phosphate receptor regulates cell migration during vertebrate heart development. Nature. 2000;406:192-5.

4. Ye D, Lin F. S1pr $2 / \mathrm{G}_{13}$ signaling controls myocardial migration by regulating endoderm convergence. Development. 2013;140:789-99.

5. Yu FX, et al. Regulation of the Hippo-YAP pathway by G-protein-coupled receptor signaling. Cell. 2012;150(4):780-91. 